OAK RIDGE NATIONAL LABORATORY

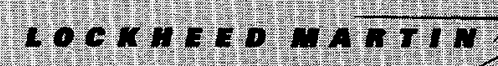

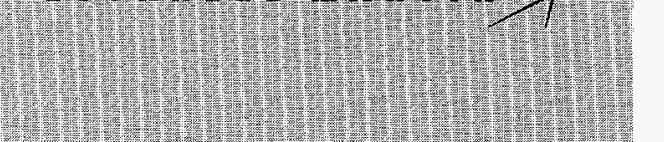
C.1.

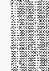

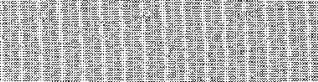
4iving

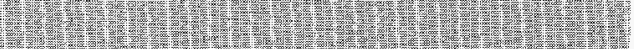

WWNAED ANO OPERATED BY LOCKHEED MARTIN ENERGY RESEARCH COAPORATION FOR THE UNTED STATES DEPARTUENT OF ENERCY

\title{
Evaluation of Measured LWR Spent Fuel Composition Data for Use in Code Validation End-User Manual
}

O. W. Hermann

M. D. DeHart

B. D. Murphy

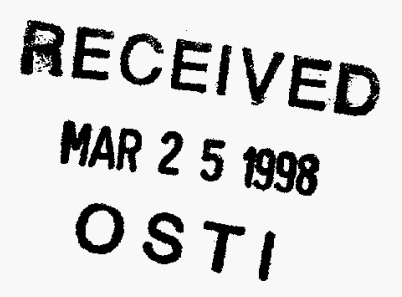

MASTER 
This report has been reproduced directly from the best available copy.

Available to DOE and DOE contractors from the Office of Scientific and Technical Information, P.O. Box 62, Oak Ridge, TN 37831; prices available from (615) 576-8401, FTS 626-8401.

Available to the public from the National Technical Information Service, U.S. Department of Commerce, 5285 Port Royal Rd., Springfield, VA 22161.

This report was prepared as an account of work sponsored by an agency of the United States Government. Neither the United States Government nor any agency thereof, nor any of their employees, makes any warranty, express or implied, or assumes any legal liability or responsibility for the accuracy. completeness, or usefulness of any information, apparatus, product, or process disclosed, or represents that its use would not infringe privately owned rights. Reference herein to any specific commercial product, process, or service by trade name, trademark, manufacturer, or otherwise, does not necessarily constitute or imply its endorsement, recommendation, or favoring by the United States Government or any agency thereof. The views and opinions of authors expressed herein do not necessarily state or reflect those of the United States Government or any agency thereof. 


\section{DISCLAIMER}

Portions of this document may be illegible electronic image products. Images are produced from the best available original document. 
Computational Physics and Engineering Division

\section{EVALUATION OF MEASURED LWR SPENT FUEL COMPOSITION DATA FOR USE IN CODE VALIDATION}

O. W. Hermann, M. D. DeHart, and B. D. Murphy

Date Published: February 1998

Prepared by the

OAK RIDGE NATIONAL LABORATORY

managed by

LOCKHEED MARTIN ENERGY RESEARCH CORP.

for the

U.S. DEPARTMENT OF ENERGY

under contract DE-AC05-96OR22464 
DOCUMENT:

TITLE:

AUTHORS:

PUBLICATION

DATE:

APPROVALS
ORNL/M-6121

Evaluation of Measured LWR Spent Fuel Composition Data for Use in Code Validation

O. W. Hermann, M. D. DeHart, and B. D. Murphy

February 1998

\begin{tabular}{lc}
\hline B. L. Broadhead, Technical Reviewer & $2-11-98$ \\
& DATE \\
\hline C. V. Parks, Technical Reviewer & $2-13-98$ \\
\hline DATE & $2-13-98$ \\
\hline C. V. Parks, Group Leader, Reactor and Fuel Cycle Analysis & DATE
\end{tabular}




\section{CONTENTS}

\section{Page}

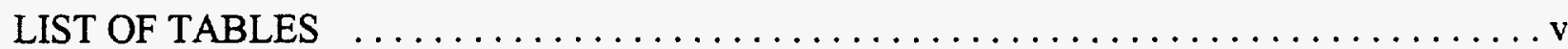

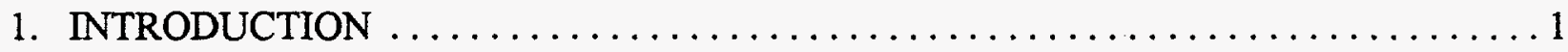

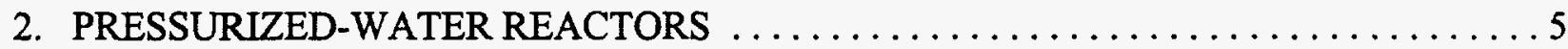

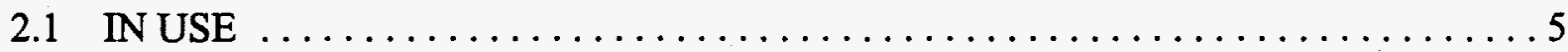

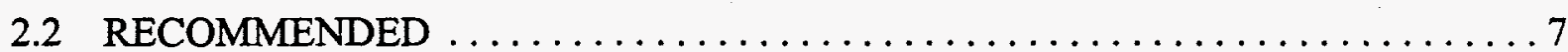

2.3 NOT RECOMMENDED $\ldots \ldots \ldots \ldots \ldots \ldots \ldots \ldots \ldots \ldots \ldots \ldots \ldots \ldots \ldots \ldots$

2.4 INSUFFICIENT DATA $\ldots \ldots \ldots \ldots \ldots \ldots \ldots \ldots \ldots \ldots \ldots \ldots \ldots \ldots \ldots$

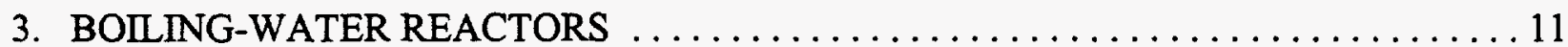

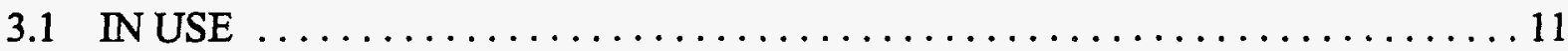

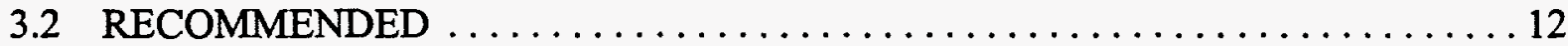

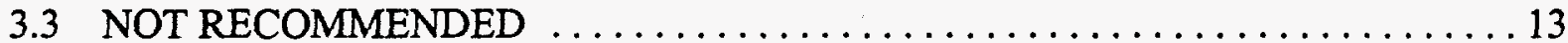

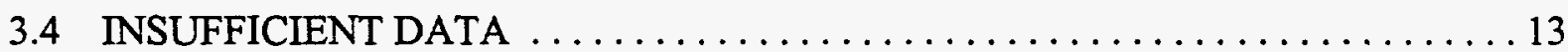

3.5 NOTE ON BWR MODERATOR DENSITIES $\ldots \ldots \ldots \ldots \ldots \ldots \ldots \ldots \ldots$

4. TEST REACTORS FOR BURNUP CREDIT VALIDATION $\ldots \ldots \ldots \ldots \ldots \ldots \ldots$

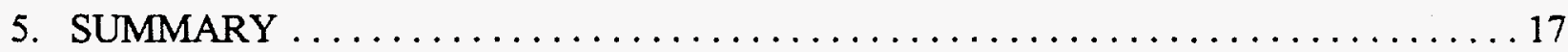

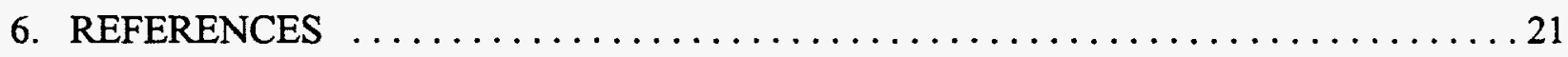




\section{LIST OF TABLES}

Table Page

1. Quantity of in-use and recommended PWR samples $\ldots \ldots \ldots \ldots \ldots \ldots \ldots \ldots$

2. Quantity of in-use and recommended BWR samples $\ldots \ldots \ldots \ldots \ldots \ldots \ldots \ldots \ldots$

3. Ranges in the burnup and enrichment of recommended PWR data $\ldots \ldots \ldots \ldots \ldots \ldots$

4. Ranges in the burnup and enrichment of recommended BWR data $\ldots \ldots \ldots \ldots \ldots$ 


\section{INTRODUCTION}

Burnup credit (BUC) is a concept applied in the criticality safety analysis of spent nuclear fuel in which credit or partial credit is taken for the reduced reactivity worth of the fuel due to both fissile depletion and the buildup of actinides and fission products that act as net neutron absorbers. Typically, a two-step process is applied in BUC analysis: first, depletion calculations are performed to estimate the isotopic content of spent fuel based on its burnup history; second, three-dimensional (3-D) criticality calculations are performed based on specific spent fuel packaging configurations. In seeking licensing approval of any BUC approach (e.g., disposal, transportation, or storage) both of these two computational procedures must be validated. This report was prepared in support of the validation process for depletion methods applied in the analysis of spent fuel from commercial light-water-reactor (LWR) designs. Such validation requires the comparison of computed isotopic compositions with those measured via radiochemical assay to assess the ability of a computer code to predict the contents of spent fuel samples.

In the performance of a thorough validation effort for commercial spent fuel depletion, it is necessary to assemble a database of appropriate measurement data for use in code comparison. It is recommended that the following issues be considered with respect to such a database:

1. The database should be of a sufficient size to obtain a good statistical sampling of trends between measured and calculated results.

2. The database should include a wide but applicable range in key depletion factors, including burnup, initial ${ }^{235} \mathrm{U}$ enrichment, moderator density, temperatures, soluble boron concentration (where appropriate), and core and assembly design.

3. Each set of data in the database should have a compilation of design and operating data as complete as possible, with minimal but clearly identified assumptions. 
4. The database should not overemphasize data taken from unusual or non-mainstream reactor designs even when such data are readily available and in a usable form. This strategy will avoid any biasing toward off-normal designs.

5. It is important to recognize that few (if any) measurements that are currently available were performed with BUC validation as a consideration. Hence, the type of fuel samples analyzed or the quality of the actual measurements may not be consistent with validation analysis requirements. Such experiments should be avoided when possible, or only appropriate subsets of data should be included. In addition, outliers found after an analysis is completed may be excluded from statistical trending and determination of computational biases, but only if the reason for outlying behavior can be identified, and would not be expected under normal operating conditions.

The purpose of this report is to address the availability and appropriateness of measured data for use in the validation of isotopic depletion methods. Although validation efforts to date at ORNL have been based on calculations using the SAS2H depletion sequence of the SCALE code system,' this report has been prepared as an overview of potential sources of validation data independent of the code system used. However, data that are identified as "in use" in this report refer to earlier validation work performed using SAS2H in support of BUC. ${ }^{2.3}$ This report is the result of a study of available assay data, using the experience gained in spent fuel isotopic validation to date and with a consideration of the validation issues described earlier. This report provides recommendations for the suitability of each set of data for validation work similar in scope to the earlier work.

Recommendations in this report are based solely on a broad ad hoc survey of available literature and the expertise of the authors. In cases where a measurement is judged unsuitable because of the lack of detailed information, it may be possible to obtain the missing data only through a reactor facility, utility company, or government agency. No effort was made to acquire such data in the performance of this literature survey, nor to assess the ease or difficulty of acquisition of such data. Data sets were classified as very complete, fairly complete, or incomplete. "Very complete" indicates minimal assumptions are necessary in model development. "Fairly complete" means that some assumptions are necessary to create a model, but that such assumptions 
are reasonable. "Incomplete" data is missing essential parameters, and model development is not possible. For completeness, this report also includes a description and ranking for each of the sets of data used in the analyses reported in refs. 2 and 3, as well as data used in a follow-up report being prepared at Oak Ridge National Laboratory (ORNL).

This report provides recommendations for further validation efforts for 19 reactors: 10 pressurized-water reactors (PWRs), 7 boiling-water reactors (BWRs), and 2 test reactors. The recommendation for use for each set of chemical assay data is graded as In Use (used in refs. 2 and 3 or in ongoing analyses), Recommended, Not Recommended, and Insufficient Data. Explanations are provided when data are categorized as Not Recommended. Experiments classified as Insufficient Data appear to be consistent with the needs of BUC, but available documentation is inadequate, and further operational and/or design data would be necessary to make a full recommendation. 


\section{PRESSURIZED-WATER REACTORS}

\subsection{IN USE}

The following sets of reactor data include samples that have been used in earlier work ${ }^{2.3,4}$ and a single set that has been analyzed but for which no results have been published to date. Not all samples have been analyzed for all sets of data. However, samples not included in the earlier work often were omitted because of poor location in an assembly, to prevent oversampling of a given assembly design, or for one or more of the selection criteria listed earlier. These criteria should be considered if additional fuel sample data are to be acquired from one of these sets of reactor data.

\section{Calvert Cliffs-1 (United States)}

The reactor design and operational data ${ }^{2,5-12}$ are very complete. Chemical analyses were conducted on three pellets from each of three fuel assemblies. The samples had a wide range in burnup and initial ${ }^{235} \mathrm{U}$ enrichment. Also, the sample rod locations relative to the guide tubes were different. The assembly design of 4-rod-locations per guide tube is not as common as 1-rod-location per guide tube.

The measurements were extensive; in particular, one pellet had 34 different nuclides analyzed. Standard deviations were reported for all measurements and were small $(1.6 \%)$ for the isotopes of uranium $(\mathrm{U})$ and plutonium $(\mathrm{Pu})$. Fission-product assays were conducted by four different laboratories.

\section{Gosgen (Switzerland)}

Under the ARIANE program coordinated by Belgonucleaire, $\mathrm{UO}_{2}$ fuel samples are being analyzed from this reactor. Reactor design and operational data are fairly complete but are not available in public documentation because of the proprietary nature of the data. However, as a participant in the ARIANE program, the U.S. government has access to the results: Two $\mathrm{UO}_{2}$ samples were irradiated from a $15 \times 15$ Siemens assembly. The ${ }^{235} \mathrm{U}$ enrichment was $3.5 \%$. One sample was burned to roughly $54 \mathrm{GWd} / \mathrm{MTHM}$, and the second, to $29 \mathrm{GWd} / \mathrm{MTHM}$. 
Mihama-3(Japan)

The reactor design data in ref. 13 did not contain pellet axial locations, from which input temperatures and moderator densities are derived. Indications suggest that there was an abnormal range in measured results for similar burnups. The use of additional pellet height data ${ }^{4}$ permits the setup of appropriate depletion models. Additional data providing the composition of burnable poison rods (BPR) and information on removal of BPRs would be useful. The scatter of calculatedto-measured ratios ${ }^{4}$ indicated that some of the data may be inappropriate. In fact, future use of this set of data for validation is not recommended, because of the unexplained variation in results where consistency would be expected; calculations performed for different axial locations within a single fuel pin showed a wide variation in measured-to-computed ratios. Such comparisons are usually consistent because all share the same geometric approximations.

\section{H. B. Robinson-2 (United States)}

The reactor design and operational data ${ }^{2,1417}$ are fairly complete. A total of six pellets were analyzed from two rods in the fuel assembly. Burnable poison rods were in the assembly for the first of two cycles. Wide ranges of burnup values and axial height locations were selected for the samples.

\section{Obrigheim (Germany): half-assembly samples}

The reactor design and operational data ${ }^{2,18,19}$ are very complete. Five assemblies were cut into halves along their axes, dissolved and sampled, so that each analysis represented the average for onehalf assembly. This method is significantly better than the use of single-pellet samples for validating point-depletion methods such as that used by $\mathrm{SAS} 2 \mathrm{H}$, because such codes are specifically intended to estimate the average nuclide densities of the assembly.

Most of the isotopes were analyzed by four separate laboratories. In addition to actinides, several fission-product ratios were measured. The ${ }^{244} \mathrm{Cm}$ was determined by alpha spectrometry, which usually has less accuracy than methods such as mass spectrometry or isotope dilution analysis. However, ${ }^{244} \mathrm{Cm}$ data are not very significant in BUC results. 


\section{Trino Vercelles (Italy)}

The reactor design and operational data ${ }^{3,13,20-22}$ are very complete. Pellet samples were taken at various heights from eight fuel rods of three assemblies irradiated for one extended cycle and, also, from six rods of another 2-cycle assembly. About half of the pellets were analyzed by two different laboratories. The reactor contained cruciform control rods (which, usually, were mostly withdrawn) and 24 cruciform fuel assemblies (permanently in core) plus the regular square fuel assemblies. The active fuel length is somewhat shorter than that of most LWRs. There is a good range in burnup (somewhat lower than average) and ${ }^{235} \mathrm{U}$ enrichment (higher than average).

\section{Turkey Point-3 (United States)}

The reactor design and operational data, ${ }^{3,10,15.23 .24}$ are fairly complete. Pellet samples were taken from five fuel rods of two fuel assemblies. The burnups changed only a small amount because the pellets were located at the same heights and the two assemblies had similar power histories. Isotopes from uranium, plutonium, and ${ }^{148} \mathrm{Nd}$ were measured. The fuel assemblies are a common design.

\subsection{RECOMMENDED}

The following two sets of reactor data are those sets that potentially represent the greatest additional benefit for BUC validation at this time. However, it does not follow that all fuel samples from each set of data are appropriate, so that individual fuel samples should be selected with sound engineering judgement and with a consideration of the guidelines for selection discussed earlier. The listing order does not indicate a ranking of the potential value of each set of data.

\section{Obrigheim (Germany): pellet samples}

The main difference between these data and the previous Obrigheim data is that measurement samples were taken from individual fuel pellets whereas the former method dissolved the entire (or half) assembly. It appears that the design and operational data ${ }^{13.18,19}$ are very complete. Seventeen samples were taken from six rods of two fuel assemblies. Most of the samples were analyzed by two different laboratories. 


\section{Yankee Rowe (USA)}

The reactor design and operational data ${ }^{4,13,15,25}$ are very complete. The nuclide analyses on numerous pellet samples are from two different programs; for reactor Cores I-IV ${ }^{13,19}$ and Core V. ${ }^{15,25}$ The more complete axially dependent temperatures and moderator densities of the latter program can possibly be used in calculations for the former program cases. Moderator boron data were also more complete in the latter program. There were wide ranges of burnups, pellet heights, and rod locations in the samples. Precise control rod data were not given. The active fuel length was somewhat shorter than that of most LWRs.

\subsection{NOT RECOMMENDED}

Three Mile Island-2 (United States)

Reference 13 has incomplete design and operational data. The power history is given prior to the accident experienced on March 28, 1979. The only measurements listed were air sample activity ratios or activity per unit volume. The nuclides xenon (Xe) and iodine (I) are of little value to BUC.

\subsection{INSUFFICIENT DATA}

The following two sets of PWR data are potential candidates for validation analyses; however, data are not readily available to make a fully informed assessment.

\section{Genkai-1 (Japan)}

The available data ${ }^{13}$ on the design and operating conditions are incomplete. Only two pellets were analyzed. If the data (e.g., power history) were better known, the pellet assay data could be used. 
Sena (Erance)

A very limited quantity of reactor design and operational data ${ }^{18}$ were available to the authors. Lattice pitch, guide tubes, densities, temperature, and precise power histories were not included. The results of radiochemical analyses were not available. However, if additional data are available, these experiments may be sufficiently complete for a good application. Based on previous experience it is likely that the measured data are considered proprietary by the French company. 



\section{BOILING-WATER REACTORS}

\subsection{IN USE}

Analysis has been recently completed for the following four BWR reactors, and draft reports are near completion. As with the PWR samples that were identified as In Use, samples not included in these analyses were omitted because of poor location in an assembly, to prevent oversampling of a given assembly design, or for one or more of the selection criteria listed earlier. Again, these criteria should be considered if additional fuel sample data are to be acquired from one of these sets of reactor data.

\section{Cooper (United States)}

The reactor design and operational data ${ }^{24,26-29}$ are fairly complete. Six pellet samples from two fuel rods of two assemblies were analyzed. There were wide ranges in burnups and sample pellet axial locations. Gadolinium was contained in 5 of the 49 rods per assembly. Only 30 of the rods had the $2.939 \mathrm{wt} \%{ }^{235} \mathrm{U}$ initial enrichment of the samples (applied in SAS2H input). Twenty nuclides were analyzed. The standard deviations of measured nuclide densities of uranium and plutonium were $1.6 \%$ and of measured burnups were $2.5 \%$.

\section{Dodewaard (Holland)}

Under the ARIANE program coordinated by Belgonucleaire, both $\mathrm{MOX}$ and $\mathrm{UO}_{2}$ fuel samples are being analyzed from this reactor. Reactor design and operational data are fairly complete but are not available in public documentation because of the proprietary nature of the data. However, as a participant in the ARIANE program, the U.S. government has access to the results. A single $\mathrm{UO}_{2}$ sample was taken from a $6 \times 6$ assembly containing primarily $\mathrm{UO}_{2}$ fuel with varying enrichments from 1.8 to $3.2 \mathrm{wt} \%$ of ${ }^{235} \mathrm{U}$. The experimental sample was an exception, containing ${ }^{235} \mathrm{U}$ with a wt $\%$ of 4.94 . 


\section{Gundremmingen (Germany)}

The reactor design and operational data ${ }^{13,27,31}$ are fairly complete. Twelve sample pellets were taken from two heights in 10 fuel rods from two assemblies. Final burnups were slightly less than typical. All sampled pellets were of the higher ${ }^{235} \mathrm{U}$ enrichment, used in 29 rods of the 36-rod assemblies. Thirteen nuclides were analyzed, mostly by two different laboratories.

Japan Power Demonstration Reactor (JPDR) (Japan)

The reactor design and operational data ${ }^{13,27}$ are fairly complete. Twenty-four sample pellets were taken from eight rods at various heights of one fuel assembly, and three pellet samples at different heights were taken from a central rod from each of two assemblies. Power histories were given in detail. Burnups were no greater than a third of the typical BWR burnup. All fuel rods had the same ${ }^{235} \mathrm{U}$ enrichment. Twenty-nine nuclides were analyzed in most of the samples. The reactor dimensions, active height, and core diameter were significantly smaller than those of the typical BWR core. JPDR data included node void fractions for each of its 38 irradiation periods.

\subsection{RECOMMENDED}

Only a single BWR dataset can be recommended at this time beyond those currently being analyzed. See Sect. 3.4 for potential candidates if additional data can be located.

\section{Garigliano (Italy)}

The reactor design and operational data for one fuel assembly ${ }^{13.22 .30}$ (A-106) are fairly complete. Samples were taken from 18 fuel rods at the same pellet height. The burnups were approximately half the typical BWR burnup. The 12 "comer" rods of the 49 rods of the assembly had a lower ${ }^{235} \mathrm{U}$ enrichment. The four "comer" rod pellet samples are not recommended for use because they would tend to have biased computed nuclide densities. The data, even though somewhat uncertain, could have limited application in code validation. 


\subsection{NOT RECOMMENDED}

\section{Monticello (United States)}

The reactor design and operational data ${ }^{10,13,32}$ are fairly complete. The average burnup of the fuel analyzed was approximately $45 \mathrm{GWd} / \mathrm{MTU}$ with sample pellets as high as $59 \mathrm{GWd} / \mathrm{MTU}$. However, this is an abnormal overburn of $2.87 \mathrm{wt} \%{ }^{235} \mathrm{U}$ fuel, which causes an excessive depletion in the ${ }^{235} \mathrm{U}$ and, to a lesser extent, ${ }^{239} \mathrm{Pu}$. A basic assumption in point depletion codes such as SAS2H is that there is a uniform lattice of the fuel assembly being analyzed. The effects from the times at which the adjacent assemblies have less reactivity (or fissile isotope density) essentially cancel the reverse effects from times where adjacent fuel has more reactivity. Also, small absolute density deviations become large percentage differences relative to the discharged low fissile nuclide densities caused by overburning. The use of high-burnup fuel in LWRs requires a corresponding increase in initial ${ }^{235} \mathrm{U}$ enrichment. Even though typical ratios of burnup to initial ${ }^{235} \mathrm{U}$ wt \% in BWR spent fuel is less than $10 \mathrm{GWd} / \mathrm{MTU} / \mathrm{wt}-\%$, the average and maximum ratios for the Monticello assembly analyzed were 16 and $20 \mathrm{GWd} / \mathrm{MTU} / \mathrm{wt}-\%$, respectively, and are therefore not representative of typical fuel. Furthermore, highly burned (over burned) assemblies will not be the limiting assemblies in any cask design, and are therefore inappropriate as a basis for isotopic uncertainties.

\subsection{INSUFFICIENT DATA}

The following three sets of BWR data are potential candidates for validation analyses; however, data were not readily available to make a fully informed assessment.

\section{Eukushima-Daiichi-3(Japan)}

The reactor design and operational data ${ }^{33}$ are incomplete. Specifically, the fuel rod diameter, clad thickness, lattice pitch, pellet density, and coolant inlet and outlet temperatures are not included. Thirty six samples were analyzed from 18 rods of seven fuel assemblies. The atomic percents of uranium isotopes for 36 samples and atomic percents of plutonium isotopes for 10 samples were reported. The ratio of $\mathrm{Pu} / \mathrm{U}$ were not included. If the data were more complete, it could be used. 


\section{Quad City-1 (United States)}

The reactor design and operational data ${ }^{13}$ are incomplete. There were 14 nuclides measured in the sample analyzed. If the data were more complete, it could be used.

\section{Tsunuga-1 (Japan)}

The reactor design and operational data ${ }^{13}$ are incomplete. Twelve samples were analyzed from two rods of two fuel assemblies. Ten of the samples were taken from the low ${ }^{235} \mathrm{U}$ enrichment rods at the corners of the assembly, which are not recommended for use here. The measurement data of the two high enrichment rods was not reported. ${ }^{13}$ If the data were more complete, it could be used.

\subsection{NOTE ON BWR MODERATOR DENSITIES}

Experience with current work on BWR validation has found that the moderator densities corresponding to the axial locations of the pellet samples are generally not included with BWR data, with the sole exception of the JPDR data. ${ }^{13}$ However, the pellet sample computed results are sensitive to the water density at the axial height of the pellet. A means to estimate axial water densities will be necessary to properly model BWR fuel depletion. 


\section{TEST REACTORS FOR BURNUP CREDIT VALIDATION}

Isotopic data from either test or commercial reactors that are not moderated by light water (e.g., those using heavy water, graphite, or sodium) are not applicable to a depletion code validation project for LWRs. Also, it does not appear to be proper to use data from LWRs with fuel-plate-type elements nor high-flux designs for production of actinides of extra high mass numbers (e.g.. ${ }^{252} \mathrm{Cf}$ ).

The experiments performed using either the MINERVE reactor ${ }^{34}$ at Cadarache, France, or the DIMPLE ${ }^{35.36}$ reactor at Winfrith, Dorset, UK, zero-power criticality facilities, have a special application to BUC applications. The first part of the BUC validation procedure would be to characterize the spent fuel from various reactors sufficiently that fuel-depletion code calculations can be performed to obtain significant nuclide compositions. These results, in turn, would then be applied to predict the reactivity of the spent fuel. The experimentalist, concurrently, would conduct high-precision measurements of reactivity worth of spent fuel similar to that used in the calculations. The comparisons of the measured and calculated reactivities would serve to validate cross-section data together with codes and methods used in predicting reactivity worth. Although this is not a direct validation of the burnup credit methodology, it does supplement other validation efforts. 


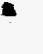




\section{SUMMARY}

Included in this report are experience-based recommendations on the use of different sets of isotopic measurement data for PWR and BWR spent fuel validation studies. The conclusions are not intended to be final but should be regarded more as a valued judgment. In particular, the acquisition of pertinent reactor design or operating condition parameters not presently available could be sufficient to make the data more highly recommended. However, the most pronounced reasons guiding these opinions were included in the above assessments of data applications for each reactor, along with other significant observations. Note that the analysis programs may have been specifically intended to analyze many of the samples from locations having the more extreme conditions, rather than a "typical" fuel sample representing average assembly conditions.

Tables 1 and 2 show the approximate number of fuel samples and assemblies that are available from all recommended or in-use cases. It is suggested that it may be best to limit the Trino Vercelles plus the Yankee Rowe analyses to an upper limit of about $30 \%$ of the total because only a limited number of PWRs have that type of design. The quantity of BWR analyses from the JPDR probably should be similarly limited. For good statistical behavior, it is considered best to use at least 40 or 50 analyses for each of the two types of LWR. Probably no fewer than 4 or 5 reactors per type should be applied. It would be desirable in the future to increase the number of appropriate sample analyses to near 100 and have 6 to 10 reactors per type. Information ${ }^{37}$ is available that states that there are both BWR and PWR fuel samples that could be analyzed if it is decided that such a program will be conducted. The BWR samples are from Dresden (35-39 GWd/MTU burnup) and from Quad Cities (60-79 GWd/MTU). (Quad Cities samples would be from four zirconium barrier fuel rods, with contents of $3.8 \mathrm{wt} \%{ }^{235} \mathrm{U}$ with no Gd burnable absorber, and $3.0 \mathrm{wt} \%{ }^{235} \mathrm{U}$ $2.0 \mathrm{wt} \% \mathrm{Gd}$ burnable absorber.) The PWR samples are from Three-Mile Island ( $60 \mathrm{GWd} / \mathrm{MTU})$. A proposed program from an overseas facility is also a possibility. Finally, note that the fuel

samples obtained from Calvert Cliffs, ${ }^{5-12}$ H. B. Robinson, ${ }^{14-17}$ and Cooper $^{26-28}$ reactors under the Pacific Northwest Laboratory's Material Characterization Center program have been archived and may be retrieved at a future date for additional measurements.

Tables 3 and 4 show the ranges in the burnup and initial ${ }^{235} \mathrm{U}$ enrichment of recommended and in use data measurements of each reactor for PWRs and BWRs, respectively. 
Table 1. Quantity of in-use and recommended PWR samples

\begin{tabular}{l|cc|ccc}
\hline \multirow{2}{*}{$\begin{array}{c}\text { Reactor } \\
\text { and/or project) } \\
\text { name }\end{array}$} & \multicolumn{2}{c|}{ No. of assemblies } & \multicolumn{3}{c}{ No. of samples } \\
\cline { 2 - 6 } & Total & Useable & Total & Min. use & Max. use \\
\hline Calvert Cliffs-1 & 3 & 3 & 9 & 9 & 9 \\
Gosgen & 1 & 1 & 2 & 1 & 2 \\
H. B. Robinson-2 & 1 & 1 & 6 & 4 & 6 \\
Mihama-3 & 3 & 3 & 9 & 5 & 7 \\
Obrigheim (dissolved) & 5 & 5 & 10 & 10 & 10 \\
Obrigheim (pellets) & 2 & 2 & 18 & 13 & 15 \\
Trino Vercelles & 3 & 1 & 36 & 10 & 15 \\
Turkey Point-3 & 2 & 2 & 5 & 5 & 5 \\
Yankee Rowe, I-IV & 14 & 4 & $\sim 300$ & 10 & 20 \\
Yankee Rowe, V & 2 & 2 & 17 & 9 & 12 \\
Totals & 36 & 24 & -400 & 76 & 101 \\
\hline
\end{tabular}

Table 2. Quantity of in-use and recommended BWR samples

\begin{tabular}{l|cc|ccc}
\hline \multirow{2}{*}{$\begin{array}{c}\text { Reactor } \\
\text { name }\end{array}$} & \multicolumn{2}{c|}{ No. of assemblies } & \multicolumn{3}{c}{ No. of samples } \\
\cline { 2 - 6 } & Total & Usable & Total & Min. use & Max. use \\
\hline Cooper & 2 & 2 & 6 & 6 & 6 \\
Dodewaard & 1 & 1 & 1 & 1 & 1 \\
Garigliano & 2 & 1 & 18 & 13 & 17 \\
Gundremmingen & 2 & 2 & 8 & 8 & 8 \\
JPDR & 3 & 3 & 30 & 16 & 21 \\
Totals & 10 & 9 & 63 & 44 & 53 \\
\hline
\end{tabular}


Table 3. Ranges in the burnup and enrichment of recommended PWR data

\begin{tabular}{lcl}
\hline \multicolumn{1}{c}{$\begin{array}{c}\text { Reactor } \\
\text { (project ID) }\end{array}$} & \multicolumn{1}{c}{$\begin{array}{c}\text { Burnup, } \\
\text { GWd/MTU }\end{array}$} & \multicolumn{1}{c}{$\begin{array}{c}\text { Initial }{ }^{235} \text { wt } \% \\
\text { Calvert Cliffs-1 }\end{array}$} \\
Gosgen & 29.68 to 46.46 & 2.45 to 2.72 \\
H. B. Robinson-2 & 16.02 to 31.66 & 2.56 \\
Mihama-3 & 8.40 to 31.40 & 3.24 \\
Obrigheim (dissolved) & 25.93 to 30.30 & 3.13 \\
Obrigheim (pellets) & 15.60 to 36.88 & 2.83 to 3.00 \\
Trino Vercelles & 3.44 to 36.88 & 2.72 to 3.90 \\
Turkey Point-3 & 30.51 to 31.31 & 2.56 \\
Yankee Rowe, I-IV & 1.32 to 32.34 & 3.40 \\
Yankee Rowe, V & 7.55 to 14.05 & 2.90 \\
\hline
\end{tabular}

Table 4. Ranges in the burnup and enrichment of recommended BWR data

\begin{tabular}{lcc}
\hline Reactor Name & $\begin{array}{c}\text { Burnup, } \\
\text { GWdMTU }\end{array}$ & $\begin{array}{c}\text { Initial }{ }^{235} \mathrm{U} \\
\text { wt \% }\end{array}$ \\
\hline Cooper & 18.96 to 33.94 & 2.94 \\
Dodewaard & 56.7 & 4.94 \\
Garigliano & 4.20 to 13.79 & 2.41 \\
Gundremmingen & 14.39 to 27.40 & 2.53 \\
JPDR & 2.16 to 7.01 & 2.60 \\
\hline
\end{tabular}


One final suggestion should be expressed concerning future spent fuel isotopic analyses conducted by the nuclear power industry: The smallest fuel unit generally unloaded from commercial LWRs, placed in interim storage, transported in shipping casks, and finally processed into repository waste by this country, or possibly reprocessed for fuel recycle by others, is the complete fuel assembly. Both nuclear criticality safety and radiation dose shielding requirements apply calculations in which the smallest unit of fuel simulated in the model usually are fuel assemblies. Thus it would appear reasonable to dissolve the entire fuel assembly, make sure it is uniformly mixed, take multiple samples and conduct analyses by several laboratories. A procedure similar to this was used on Obrigheim ${ }^{18}$ PWR fuel assemblies, except that the assemblies were split along the axis into two halves before dissolving. The cost of using the assembly-dissolving procedure may be prohibitive. Building or even reopening a facility for this purpose would be both expensive and time consuming. It may be cost effective to do this at an overseas facility. Increased efficiencies in storage and shipping operations could make it cost effective. In using Obrigheim data only in the validation study ${ }^{2}$ for the 44-group library, for example, the average percentage differences (disregarding the signs) between computed and measured results for the five plutonium isotopes were $0.9 \%$, or excluding ${ }^{242} \mathrm{Pu}$, an average of $0.5 \%$. The average difference for ${ }^{239} \mathrm{Pu}$ was $<0.1 \%$. 


\section{REFERENCES}

1. SCALE. A Modular Code System for Performing Standardized Computer Analyses for Licensing Evaluation, NUREG/CR-0200, Rev. 5 (ORNL/NUREG/CSD-2/R5), Vols. I-III (March 1997). Available from Radiation Shielding Information Center, Oak Ridge National Laboratory, as CCC-545.

2. O. W. Hermann, S. M. Bowman, M. C. Brady, and C. V. Parks, Validation of the SCALE System for PWR Spent Fuel Isotopic Composition Analyses, ORNL/TM-12667, Martin Marietta Energy Systems, Inc., Oak Ridge Natl. Lab., 1995.

3. M. D. DeHart and O. W. Hermann, An Extension of the Validation of SCALE (SAS2H) Isotopic Predictions for PWR Spent Fuel, ORNL/TM-13317, Lockheed Martin Energy Research Corp., Oak Ridge Natl. Lab., September 1996.

4. M. Rahimi, E. Fuentes, and D. Lancaster, Isotopic and Criticality Validation for PWR Actinide-Only Burnup Credit, DOE/RW-0497, JAI Co. and TRW Environmental Safety Systems Inc. for USDOE Office of Civilian Radioactive Waste Management, 1997.

5. R. J. Guenther et al., Characterization of Spent Fuel Approved Testing Material - ATM-103, PNL-5109-103, Pacific Northwest Laboratory, 1988.

6. R. J. Guenther et al., Characterization of Spent Fuel Approved Testing Material-ATM-104, PNL-5109-104, Pacific Northwest Laboratory, 1991.

7. R. J. Guenther et al., Characterization of Spent Fuel Approved Testing Material - ATM-106, PNL-5109-106, Pacific Northwest Laboratory, 1988.

8. S. R. Bierman, Benchmark Data for Validating Irradiated Fuel Compositions Used in Criticality Calculations, SAND 94-0860 (TIC-1044), Pacific Northwest Laboratory, 1994.

9. S. R. Bierman, "Spent Reactor Fuel Benchmark Composition Data for Code Validation," Proc. of International Conference on Nuclear Criticality Safety, Oxford, United Kingdom, September 1991.

10. J. W. Roddy et al., Physical and Decay Characteristics of Commercial LWR Spent Fuel, ORNL/TM-9591, Martin Marietta Energy Systems, Inc., Oak Ridge Natl. Lab., October 1985.

11. R. J. Guenther, D. E. Blahnik, and N. J. Wildung, Radiochemical Analyses of Several Spent Fuel Approved Testing Materials, PNL-10113, Battelle Pacific Northwest Laboratory, 1994. 
12. S. R. Bierman and R. J. Talbert, Benchmark Data for Validating Irradiated Fuel Compositions Used in Criticality Calculations, PNL-10045, Battelle Pacific Northwest Laboratory, 1994.

13. Y. Naito, M. Kurosawa, and T. Kaneko, Data Book of the Isotopic Composition of Spent Fuel in Light Water Reactors, JAERI-M 94-034, Japan Atomic Energy Research Institute, 1994.

14. J. O. Barner, Characterization of LWR Spent Fuel MCC-Approved Testing Material - ATM101, PNL-5109, Rev. 1, Pacific Northwest Laboratory, 1985.

15. J. C. Ryman et al., Fuel Inventory and Afterheat Power Studies of Uranium-Fueled Pressurized Water Reactor Fuel Assemblies Using the SAS2 and ORIGEN-S Modules of SCALE with an ENDF/B-V Updated Cross Section Library, NUREG/CR-2397 (ORNL/CSD-90), Union Carbide Corp., Nucl. Div., Oak Ridge Natl. Lab., September 1982.

16. Letter, O. Ozer of Electric Power Research Institute to W. B. Lowenstein and B. A. Zolotar, "EPRI-CELL Test Calculations of Isotopes as a Function of Burnup," April 1976.

17. "Robinson 2," Section in Nuclear Power Experience, Plant Descriptions, and Histories, Vol. PWR-1, p. 5, August 1981.

18. U. Fischer and H. W. Wiese, Improved and Consistent Determination of the Nuclear Inventory of Spent PWR Fuel on the Basis of Cell Burnup Methods Using KORIGEN (ORNL-TR-5043), KFK 3014, Karlsruhe Nuclear Research Center, January 1983; available from Radiation Shielding Information Center, Oak Ridge National Laboratory, as CCC-457.

19. U. Hesse, Verification of the ORSET (HAMMER-ORIGEN) Depletion Program System Using Post-Irradiation Analyses of Fuel Assemblies 168, 170, and 176 from the Obrigheim Reactor (ORNL-TR-88/20), GRS-A-962, Gesellschaft für Reaktorscherheit (GRS) mbH, 1984.

20. A. M. Bresesti et al., Post-Irradiation Analysis of Trino Vercelles Reactor Fuel Elements,EUR-4909e, Joint Nuclear Research Centre Ispra and Karlsruhe Establishments, 1972.

21. P. Barbero et al., Post-Irradiation Examination of the Fuel Discharged from the Trino Vercelles Reactor After the $2^{\text {nd }}$ Irradiation Cycle, Nuclear Science and Technology, EUR5606e, Joint Research Centre Ispra and Karlsruhe Establishments, 1977.

22. S. Guardini and G. Guzzi, Benchmark Reference Data on Post Irradiation Analysis of Light Water Reactor Fuel Samples, EUR7879en, Joint Research Centre Ispra, 1983. 
23. S. D. Atkin, Destructive Examination of 3-Cycle LWR Fuel Rods from Turkey Point Unit 3 for the CLIMAX-Spent Fuel Test, HEDL-TME 80-89, Hanford Engineering Development Laboratory, 1981.

24. O. W. Hermann, C. V. Parks, and J. P. Renier, Technical Support for a Proposed Decay Heat Guide Using SAS2H/ORIGEN-S Data, NUREG/CR-5625 (ORNL-6698), U.S. Nuclear Regulatory Commission, 1994.

25. J. B. Melehan, Yankee Core Evaluation Program Final Report, WCAP-3017-6094, Westinghouse Electric Corp., 1971.

26. R. J. Guenther et al., Characterization of Spent Fuel Approved Testing Material - ATM-105, PNL-5109-105, Pacific Northwest Laboratory, 1991.

27. O. W. Hermann et al., Multicode Comparison of Selected Source Term Computer Codes, ORNL/CSD/TM-251, Martin Marietta Energy Systems, Inc., Oak Ridge Natl. Lab., April 1989.

28. U.S. Department of Energy, Characteristics of Potential Respository Wastes, DOE/RW0184-R1, Vol. 1, Oak Ridge Natl. Lab., July 1992.

29. M. A. McKinnon, C. M. Heeb, and J. M. Creen, Decay Heat Measurements and Predictions of BWR Spent Fuel, EPRI NP-4619, Electric Power Research Institute, June 1986.

30. A. Ariemma et al., Experimental and Theoretical Determination of Burnups and Heavy Isotope Content in a Fuel Assembly Irradiated in the Garigliano Boiling Water Reactor, EUR4638e, ENEL and EURATOM, 1971.

31. P. Barbero et al., Post-Irradiation Analysis of the Gundremmingen BWR Spent Fuel, EUR6301en, Joint Research Center Ispra and Karlsruhe Establishments, 1979.

32. Characteristics of Potential Repository Wastes - Appendix 2A. Physical Descriptions of LWR Fuel Assemblies, DOE/RW-0184-R1, Vol. 1, U.S. Department of Energy, July 1990.

33. M. Kurosawa, Y. Naito, H. Sakamoto, and T. Kaneko, The Isotopic Compositions Database System on Spent Fuels in Light Water Reactors (SFCOMPO), JAERI-Data/Code 96-036, Japan Atomic Energy Research Institute, 1996.

34. A. Santamarina et al., "Experimental Validation of Burnup Credit Calculations by Reactivity Worth Measurements in the MINERVE Reactor," Proc. of the Fifth Interational Conference on Nuclear Criticality Safety, Albuquerque, N.M., Sept. 17-21, 1995.

35. J. Gulliford, D. Hanlon, and M. Murphy, "Experimental Validation of Calculational Methods and Data for Burnup Credit," Proc. of the Fifth International Conference on Nuclear Criticality Safety, Albuquerque, N.M., Sept. 17-21, 1995. 
36. A. D. Knipe, The CERES Experimental Programme in DIMPLE, CSE/P(91)1, June 1991.

37. O. Ozer, Subject: RE: Spent Fuel Isotopes, E-mail sent from O. Ozer at EPRI to C. V. Parks at ORNL, August 21, 1997.

38. M. D. DeHart and O. W. Hermann, Validation of SCALE (SAS2H) Isotopic Predictions for BWR Spent Fuel, ORNL/TM-13315, Lockheed Martin Energy Research Corp., Oak Ridge Natl. Lab. (Draft, 1997). 


\section{INTERNAL DISTRIBUTION}

1. S. M. Bowman

2. B. L. Broadhead

3-7. W. C. Carter

8-9. M. D. DeHart

10-14. O. W. Hermann

15. M. A. Kuliasha
16. B. D. Murphy

17-18. C. V. Parks

19. C. H. Shappert

20. Central Research Library

21. Lab Records Department - RC

22-23. Lab Records for submission to OSTI

\section{EXTERNAL DISTRIBUTION}

24. M. Anderson, Framatome Cogema Fuels, 1180 Town Center Drive, Las Vegas, NV 89134

25. T. W. Doering, Framatome Cogema Fuels, 1180 Town Center Drive, Las Vegas, NV 89134

26. D. Henderson, Framatome Cogema Fuels, 1180 Town Center Drive, Las Vegas, NV 89134

27-31. C. W. Mays, Framatome Cogema Fuels, 3315 Old Forest Road, P. O. Box 10935, Lynchburg, VA 24506-0935

32. J. J. Sapyta, Framatome Cogema Fuels, 3315 Old Forest Road, P. O. Box 10935, Lynchburg, VA 24506-0935

33-37. D. A. Thomas, Framatome Cogema Fuels, 1180 Town Center Drive, Las Vegas, NV 89134 